\title{
Social Interaction Between Indigenous and Non-Indigenous Community in Malaysia
}

\author{
*Nola Aprilia Sukhaimia ${ }^{1}$ and Susilawati Sinurat ${ }^{2}$ \\ 1) Graduate Student of Geography Education, Universitas Negeri Padang, Indonesia \\ e-mail: nolasukhaimi5@gmail.com \\ 2) Student of Geography, Malaya University, Malaysia \\ e-mail: suzysinurat69@gmail.com
}

*Corresponding Author, Received: September 14, 2018, Revised: October 21, 2018, Accepted: December 05, 2018

\begin{abstract}
This study aims to collect, process, analyze and describe social interactions between indigenous and nonindigenous communities in Malaysia. This research is a descriptive study using qualitative data. Data collected using techniques, interviews, and documentation. Data analysis in the study was carried out using data reduction techniques, data interpretation and reduction of conclusions. The results showed that the Malay or indigenous community consisting of native Malaysians and Islamic and non-indigenous majority consisted of Chinese, Indians, Arabs and Thais, where they interacted with indigenous and non-indigenous populations who had an influence on the growth of life the community. The form of interaction varies based on motivation and interaction. 1) Interaction is carried out for business transactions because many tourists go to Malaysia as a consumer and businessman as a means of the necessary facilities.2) Interaction activities when indigenous and non-indigenous communities meet at work, tourist attractions, schools, hospitals, highways. The meeting was like in school with motivation for friendship, finance, and romance. 3) Interactions that occur when both parties explore information such as culture, language, and personal data. Interaction is more common when both parties go to a place and make a meeting. Interaction can be distinguished between indigenous and non-indigenous communities from language and physical form differences. The impacts of these changes are relationships, social, cultural, and linguistic.
\end{abstract}

Keywords: Social, Indigenous, Non-Indigenous Interactions

\section{Introduction}

Malaysia is the 43rd most populous country and the 66th largest country in the world, with a population of approximately 27 million and has an area with various ethnicities, languages, cultures, religions and food. Malaysia, which is a federated country, is divided into 13 states and 3 partnership territories administratively. Indigenous people, in this case, are called Malays and non-natives are called non-Malay tribes. Malay tribe is a name that refers to a group whose main characteristic is the narration of Malay. Malays live in much of Malaysia, the east coast of Sumatra, around the coasts of Kalimantan, southern Thailand, and small islands stretching along the Malacca Strait and Karimata Strait. The Malay Malaysian people called KaumMelayu are Malay people who are Malays native to the Malay Peninsula (Malay Teak Children), plus immigrant tribes from Indonesia and other places called MelayuAnakDagang such as Java, Minangkabau, Riau, Mandailing, Aceh, Bugis, Bawean, Banjar, Champa and others. All are bound by Islam and Malaysian Malay culture. Other Muslim races are also categorized as Malays, such as Muslim Chinese, Muslim Indians and Arabs. So that Malay also calledethnoreligius which is the "Muslim community of 
Malaysia" in Malaysia. Malay or indigenous people consisting of native Malaysians with majority Islamic and non-indigenous people consist of Chinese, Indians, Arabs and Thai. Enhancement population growth over time impact on increased development (Jonah, 2008) Rapid development has been causing changes in land use patterns (Umar, 2017; Hermon et al., 2018). Basically, every individual is a social being, who has an instinct to live in a community environment both the physical environment and psychological environment in which mutual relations occur between individuals with each other. This is because since born humans already have two basic desires or needs, which are: the desire to become one with other people around them, namely the community and also the desire to become one with the surrounding natural atmosphere (Khotimah, 2016). Social interaction can be interpreted as dynamic social relationships (Hermon, 2010a). Social relations can be in the form of relationships between one individual and another, between one group and another, and between groups and individuals (Hermon, 2012; Hermon, 2015a). In interaction, there is also a symbol, where the symbol is defined as something which is value or meaning is given to them by those who use it (Hermon, 2016; Hermon, 2017). Social interaction in the present time is indeed different from the form of interaction in ancient times (Hermon, 2014; Hermon, 2015b). Initiate by face to face social interaction (oral) (Macionis and Plummer, 2005) and followed by writing and printing social interaction (Asmi, 2004). In general, social interactions conducted on social media are the same as conventional face-to-face interactions (Sallehuddin and Sukimi, 2014). Walgito (2003) suggests that in the interaction of social relationships between individuals one with other individuals, one individual can influence the other individual or vice versa so that there is a reciprocal relationship. Social interaction is dynamic social relations that concern the relationship between individuals and human groups (Father in Soekanto, 2012). Social interaction is an individual way to maintain individual social behaviour so that individuals can still behave socially with other individuals (Fatnar, 2014; Oktorie, 2017; Oktorie, 2018). Community social interaction is related to a sense of togetherness that is manifested in a communication regarding moral attitudes and agreements on religious, ethnic and indigenous communities to create a harmonious environment (Abral, 2017; Hermon, 2009; Hermon, 2010b). Malay is a reflection of unity between Islamic values and the locality of the community contained in it, one cannot be called Malay if he leaves Islam in himself and in his life (Sunandar, 2015). Malay-Islam is the centre of civilization, the centre of cultural development and an important trading centre (Baharuddin \& Nazli, 2014).

\section{Method}

Based on the problems discussed in this study and the objectives are to find out the social interaction between indigenous people and non-indigenous communities in Malaysia. This research is a type of descriptive research with qualitative data from primary and secondary data (Hermon et al., 2008). Descriptive research is not to test the correctness of the hypothesis but only describes the existence of a variable, symptom or condition. This research was conducted in several places in Malaysia such as the University of Malaya, Jamek Mosque, Art Market, Wang River Mall, Kuala Lumpur City Council (DBSA), Batu Caves Temple, Kajang, Bukit Bintang, Putrajaya Mosque, Putrajaya Wetland Park. The research was conducted with a span of time between July 7-12 2018. Data collection was carried out by interview, observation and documentation. The informants in this study were students of Universiti Malaya, Lecturers at Universiti Malaya, grab driver, as well as indigenous and non-indigenous communities who were found in tourist attractions in Malaysia that researcher considered had the competence in providing information about expected research data, which is about social interaction between indigenous people and non-indigenous communities in Malaysia. Data analysis was carried out with data reduction techniques. Data reduction is an electoral process, which focuses attention on simplification, abstracting, rough data transformation that arises from records in the field (Miles and Huberman, 2015). The steps were taken in data reduction by sharpening analysis, categorizing into each problem briefly, directing, removing unnecessary and organizing data so that they can be withdrawn and verified. The reduced data include all data regarding research problems. Reduced data will provide a more specific picture and make it easier for researchers to conduct further data collection and find additional data if needed. The longer the researcher in the field, the data will be more complex and complicated. Therefore, data reduction needs to be done so that data is not piled up in order not to complicate further analysis. Data interpretation is the data obtained from searching for the meaning contained in it and then presented using words and sentences that are easy to be understood and then draw the conclusions. In this research, the researcher tries to get information about the variables under study, so the data obtained 
from the field that has been collected and analyzed draws conclusions and finally will be the result of the research.

\section{Results and Discussion}

Indigenous people, in this case, are Malay people, which majority of them are Muslims, and indigenous people are not Malay people, consisting of Chinese, Indians, Arabs, and Thais. Malaysia known as a federal state consists of thirteen countries (states) and three federal regions in Southeast Asia with an area of 329,847 sq. Km. With the capital in Kuala Lumpur, while Putrajaya became the centre of the federal government. The Malaysian state, which was only established 60 years ago, used to need foreign workers to develop the Malaysian State in terms of the construction of facilities and infrastructure, communication networks, thus requiring personnel imported from China, India and even from Indonesia (especially the Javanese) However, infrastructure development in Malaysia is currently being replaced by many Bangladeshis over time. Chinese and Indians as non-indigenous people do a lot of trading activities in Malaysia such as the sale of souvenirs, foods, electronic equipment and so on. Social interaction was formed from activities carried out by indigenous and non-indigenous communities in Malaysia. Humans interact with each other in life to produce social interactions in a social group (Halikin, 2014). The form of interaction varies based on motivation and the actors themselves. Interaction occurs if there is a relationship of two or more people which conduct a meeting that discusses the issues of education, health, politics, culture, language and matters related to personal data. Social interactions that exist between indigenous and nonindigenous communities are going well, so there are no issues that can damage the harmony of society. Interaction occurs because of the need factor between the interaction actors. From observing the situation on the ground, the researcher found that Malays are more likely to interact with Malays, as well as Chinese and Indians are more likely to interact with their fellowmen, this is due to similarities, place of residence, background, education, culture and language. When interacting with non-indigenous people, the language used is Malay with a mixture of English as an international language. The number of tourists coming to Malaysia makes a lot of social interaction between Malay people and non-Malay people. This interaction occurs when both parties explore information, such as tourism, culture and personal data.

Interaction often occurs when people meet in a place such as a café or a restaurant around campus or in tourist attractions. Interaction will occur intensely if two parties have known each other for a long time. Interaction can be different between students and non-students and between workers and non-workers. Based on the description above, it can be stressed that the social interaction of indigenous and non-indigenous communities in Malaysia is good enough so that does not cause social distortion in the process of interacting. Other information states that mosques have a real role in building social reform between indigenous people and non-indigenous communities. It is because Malaysia is predominantly Muslim. Then in terms of tourism services and the absence of payments made for tourism places, so it will attract tourists to come and make social interaction with the indigenous community. This interaction is considered to be very capable of attaching the social relations of indigenous people to non-indigenous communities. This also shows that the existence of non-indigenous people towards indigenous communities is highly valued, respected and open to newcomers. Of course, this has a very positive impact, both by indigenous people and non-indigenous communities in a whole society. Interaction that exists between indigenous and non-indigenous communities in Malaysia is a relationship that mutually influences one another, even with the surrounding environment, in this case there is an advantage between the two sides and creates a harmonious and comfortable life form in social life, religion, culture, language and so on that can be realized in the form of solidarity, tolerance and respect for the surrounding community. In the view of indigenous people, non-indigenous people have a positive life, such as enthusiasm and perseverance in working and having a high creativity. They also seemed friendly and simple which is the nature of non-indigenous people such as people who come from Indonesia in order to travel.

\section{Conclusion}

Based on the results of the research that the author got from the data of observation, interviews and documentation studies as well as the discussion above, the conclusions the authors get from research on the 
social interaction of indigenous and non-indigenous communities in Malaysia are as follows: Interaction is done for business transactions, because the number of tourists who go on holiday to Malaysia as consumers and business actors as providers of the necessary facilities. Interaction occurs when indigenous and nonindigenous communities meet at work, tourist attractions, schools, hospitals, highways. The meeting is like in school with friendship, financial, and romantic motivation. Interaction occurs when both parties share information, both about tourism, culture, language, and personal data. The social interaction of indigenous and non-indigenous communities in Malaysia goes well and harmoniously so that it leads to the nature of demonstration, tolerance, motivation and mutual respect between one community and another.

\section{References}

Abral, W. 2017. The Formulation of Student Social Interaction Model at Halal Tourism Area on Lombok Island. Sumatra Journal of Disaster, Geography and Geography Education ISSN: 2580-4030 (Print) 2580-1775 (Online) Vol 1, No. 2, (pp. 234-241), December 2017 http://sjdgge.ppj.unp.ac.id

Asmi, M. 2004. Rekabentuk dan Pelaksanaan Terminal VoIP. (Latihan Ilmiah).Universiti Sains Malaysia.

Baharuddin and N., Mohamad. 2014. Islam and Malaya Culture Era Globalization in Malaysia. Social Culture: Media Communication Social and Cultural Sciences, KolejUniversiti Islam Melaka, Vol.10, January 1-June 2014.

Fatnar, V. N. 2014. The Capability of Social Interaction Between the Adolescent Stay in Pondok Pesantren with that Stay whit Family. Volume 2, No 2

Halikin. 2014. Analisis Pola Interaksi Masyarakat Pendatang terhadap Masyarakat Lokal di Sumbawa Barat studi di KecamatanMaluk, Sumbawa Barat, NTB. Fakultas Ilmu Tarbiyah dan Keguruan UIN Syarif Hidayatullah Jakarta.

Hermon, D., Khairani., Daswirman., S. Karim., Dasrizal., and Triyatno. 2008. Metode dan Teknik Penelitian Geografi Tanah: Aplikasi Instrumen dan Acuan Penelitian Geografi Fisik. Yayasan Jihadul Khair Center.

Hermon, D. 2009. Dinamika Permukiman dan Arahan Kebijakan Pengembangan Permukiman pada Kawasan Rawan Longsor di Kota Padang. Disertasi. IPB Bogor.

Hermon, D. 2010a. Geografi Lingkungan: Perubahan Lingkungan Global. UNP Press.

Hermon, D. 2010b. Arahan Kebijakan Pengembangan Permukiman pada Kawasan Rawan Longsor di Kota Padang. Jurnal SKALA. Vol. 1.

Hermon, D. 2012. Mitigasi Bencana Hidrometeorlogi: Banjir, Longsor, Degradasi Lahan, Ekologi, Kekeringan, dan Puting Beliung. UNP Press. Padang.

Hermon, D. 2014. Desain Kebijakan Tanggap Darurat dan Pemulihan Bencana Letusan Gunung Sinabung. Seminar Nasional Geografi. Master Program of Geography Education, Universitas Negeri Padang.

Hermon, D. 2015a. Geografi Bencana Alam. Jakarta: PT RajaGrafindo Persada.

Hermon, D. 2015b. Arahan Kebijakan Keberlanjutan Pendidikan 10 Tahun Pasca Bencana Tsunami di Kabupaten Aceh Jaya Provinsi Aceh. Seminar Nasional Geografi. Master Program of Geography Education, Universitas Negeri Padang.

Hermon, D. 2016. Mitigasi Perubahan Iklim. Rajawali Pers (Radjagrafindo).

Hermon, D., Y. Suasti., Ernawati., Afdhal., and H. Edial. 2018. Geografi: Geografi untuk SMU. Jurusan Geografi Universitas Negeri Padang.

Khotimah. 2016. Social Interaction of Islamic and Christian Society in Dusun IV Tarab Mulia Sub District Kabupaen Kampar. Kutub khanah: Journal Religious Social Research, Vol.19, No.2 Juli-Desember 2016

Macionis, J.J and Plummer, K. 2005. Sociology.Edisi Ke-3. Prentice Hall, United States of America.

Miles and Huberman. 2015. Analisis Data Kualitatif Buku Sumber tentang Metode-Metode Baru. Jakarta: UI Press. 
Oktaviyanti, S. S. 2013. Dampak Sosial Budaya Interaksi Wisatawan dengan Masyarakat Lokal di Kawasan Sosrowijayan.Pusat Studi Pariwisata. Universitas Gadjah Mada. Vol.5, No 3

Oktorie, O. 2017. A Study of Landslide Areas Mitigation and Adaptation in Palupuah Subdistrict, Agam Regency, West Sumatra Province, Indonesia. Sumatra Journal of Disaster, Geography and Geography Education. Volume 1. Issue. 1. p: 43-49. Master Program of Geography Education.

Oktorie, O. 2018. Model Kebijakan Responsif Pemulihan Bencana Letusan Gunung Sinabung. Jurnal Kapita Selekta Geografi. Volume 1. Issue 1. p: 15-20

Umar, I., Widiatmaka, W., Pramudya, B., and Barus, B. 2017. Evaluasi Kesesuaian Lahan untuk Kawasan Permukiman dengan Metode Multi Criteria Evaluation di Kota Padang. Jurnal Pengelolaan Sumberdaya Alam dan Lingkungan (Journal of Natural Resources and Environmental Management), $7(2), 148-154$.

Saalehuddin, M., M. Khairuddin and S. M. Fauzi. 2014. Interaksi Sosial di Ruang Maya: Kajian Kes Jaringan Sosial melalui Laman Facebook di Malaysia. GEOGRAFIA Online TM Malaysian Journal of Society and Space 10 Issue 6 (138-147), ISSN 2180-2491

Soekanto, S. 2012 .Sosiologi Suatu Pengantar. Jakarta: RajawaliPers

Sunandar. 2015. Melayu in The Challenges of Globalization: Reflections on the History and Changing of Cultural Reference Systems.Khatulistiwa Journal-Journal of Islamic Studies. Vol. 5, No. 1, Mar 2015.

Walgito, B. 2003. Psikologi Sosial Suatu Pengantar. Yogyakarta: Andi Offset. 